\title{
KESADARAN PHONOLOGI DENGAN LITERASI MEMBACA PADA ANAK DISLEKSIA: KAJIAN META ANALISIS
}

\author{
Trubus Raharjo \\ Program Doktor Ilmu Psikologi Fakultas Psikologi Universitas Gadjah Mada \\ trubuspsi@gmail.com
}

\begin{abstract}
Abstrak
Meta analisis ini bertujuan untuk mengetahui hubungan kesadaran phonologi dengan literasi membaca pada anak disleksia. Disleksia merupakan salah satu bentuk gangguan neuropsikologi pada individu yang berkaitan denga literasi membaca. Literasi membaca merupakan kemampuan kognitif untuk memasukkan informasi, menyimpan dan memproses phonologi. Seorang dengan kemampuan membaca yang buruk dapat dipengaruhi oleh kesadaran phonologi. Literasi membaca dapat dipengaruhi oleh kesadaran phonologi. Sebanyak 2080 sampel dan 27 data hubungan kesadaran phonologi dengan literasi membaca dikumpulkan dari 20 naskah yang dipublikasikan rentang tahun 2001 - 2015. Lokasi observasi dari studi-studi tersebut mencakup benua Asia, Eropa, Amerika. Hasil analisis data pada studi meta analisis ini menunjukkan bahwa hubungan tersebut tergolong sedang dengan korelasi (ř) sebesar 0.53 , standar deviasi (SD) sebesar 0.373 , dan interval kepercayaan berada pada rentang $-0.591<\check{r}<0.837$, artinya nilai $(\check{r})$ dapat diterima. Hasil ini menunjukkan bahwa hipotesis yang menyatakan bahwa ada hubungan antara kesadaran phonologi dengan literasi dapat diterima.
\end{abstract}

Kata kunci : Kesadaran phonologi, Disleksia, Literasi membaca.

\begin{abstract}
This meta-analysis aims to determine the phonological awareness relationship with reading literacy in dyslexic children. Dyslexia is a form of neuropsychological disorder in individuals related to reading literacy. Reading literacy is a cognitive ability to process information, store and processing phonology. A person with lack of reading ability can be influenced by phonological awareness. Reading literacy can be influenced by phonological awareness. A total of 2080 samples and 27 data on phonological awareness relationships with reading literacy were collected from 20 manuscripts published in 2001 2015. The locations of observations from these studies included the continents of Asia, Europe, America. The results of the data analysis in this meta-analysis showed that the relationship was classified as moderate with a correlation (r) of 0.53, standard deviation (SD) of 0.373 , and the confidence interval was in the range of $-0.591<\check{r}<0.837$, meaning that the value $(\check{r})$ was acceptable . These results indicate that the hypothesis that there is a relationship between phonological awareness and literacy can be accepted.
\end{abstract}

Keywords: Phonological awareness, Dyslexia, Reading literacy

(c) 2018 Universitas Muria Kudus 


\section{PENDAHULUAN}

Membaca merupakan salah satu komponen penting dalam bidang akademik di sekolah atau dengan membaca seseorang akan mewujudkan tujuan yang hendak dicapai (Gothrie, Alao, Rinehart,1996). Perilaku membaca yang komplek akan melibatkan kemampuan berpikir, dan setiap kata dalam membaca itu sendiri menunjukkan berbagai aktivitas yang berbeda (Beaton, 2004). Saat membaca membutuhkan kemampuan interaktif di mana pembaca memberikan makna yang didasari pada bacaan berdasarkan latar belakang pengalamannya, sehingga terjadi interaksi antara pembaca dengan bacaan (Afangideh \& Jude, 2012). Literasi membaca akan melibatkan berbagai kemampuan kognitif yang komplek, termasuk kemampuan seseorang untuk memasukkan informasi, menyimpan dan memproses phonologi, visual dan kinestetik dan mengontrol gerakan dari mata serta tangan (Singleton, 2002).

Ketidakmampuan membaca didiagnosis pada anak-anak yang mengalami kegagalan untuk membangun kemampuan membaca meskipun pada keadaan inteligensi yang normal, kurangnya motivasi yang tepat dan adanya permasalahan neurotik maupun psikiatri (Lorusso dkk, 2011). Bentuk gangguan neurologis, yang sering terjadi pada bahasa, dalam penerimaan dan ekspresi bahasa, termasuk proses pengejaan, dalam membaca, mengeja, menulis dan aritmatika disebut sebagai disleksia (Asosiasi Disleksia Internasional, 1994). Gangguan ketidakmampuan membaca ini biasanya mulai terlihat nyata pada tahun pertama anak sekolah sesegera setelah anak-anak belajar membaca (Lorusso, 2011).

Komponen utama disleksia adalah ketidakmampuan secara literasi dalam kesulitan belajar, secara khusus kesulitan dalam merekognisi kata, pengejaan dan merekam bunyi bahasa, di mana kemampuan merekam bunyi bahasa merupakan kemampuan untuk menbahasakan dan membuat pola dari bentuk bunyi bahasa (Fuchs \& Fuchs, 2006). Menurut Shaywitz \& Shaywitz (Nelzon \& Ellison, 2009), disleksia merupakan bentuk kesulitan belajar yang spesifik yang berasal dari neurobiologi, yang merupakan karakteristik dari kesulitan terhadap ketepatan atau kelancaran merekognisi kata-kata, serta kekurangan dalam mengeja dan kemampuan mengkode kata. Tipe-tipe kesulitan yang merupakan hasil dari ketidakmampuan menyerap komponen phonologi dalam bahasa. Hal tersebut sering merupakan suatu yang tidak diharapkan dari kemampuan kognitif dan ketentuan instruksi kelas yang efektif.

Beberapa penulis lain mengajukan beberapa perbedaan tipe-tipe disleksia yang dapat diidentifikasi. Beberapa pembagian tersebut menerapkan prosedur dari kelompok-kelompok statistik agar supaya diidentifikasi pada kelompok yang dikarakteristikkan dengan perbedaan profil neuropsikologis (Petrauskas \& Rourke, 1979; Wolf \& Bowers:1999).

Banyak penelitian yang berkonsentrasi pada korelasi antara kemampuan kognitif dan neuropsikologi dengan kemampuan membaca, seperti kemampuan ingatan verbal jangka 
pendek (Velluntino, 1990). Santrock, (2011), meneliti disleksia sebagaimana tipe kesulitan belajar lain kemungkinan besar tidak melibatkan lokasi otak tertentu, namun lebih disebabkan oleh masalah-masalah dalam mengintegrasikan informasi dari sebagian otak atau kesulitan yang tidak kentara dalam struktur dan fungsi otak.

Literasi membaca

International Association for the Evaluatiaon of Educational Echeivement (IEA) (Shiel, 2002), mendefinisikan literasi sebagai kemampuan untuk memahami dan menggunakan bentuk bahasa tulisan yang dibutuhkan oleh masyarakat dan atau nilai-nilai individu. Dalam penelitian yang dilakukan melibatkan siswa yang diukur dari 3 tipe kemampuan terhadap teks bacaan, 1) Naratif teks yaitu subyek diminta untuk menulis suatu cerita, bisa nyata atau fiksi. 2). Dukumen teks yaitu siswa diminta untuk membaca dalam bentuk bacaan,atau kartu. 3) Ekspositori teks yaitu prosa yang didesain untuk dijelaskan atau menyampaikan informasi yang faktual.

Difinisi singkat dari literasi adalah kemampuan untuk membaca dan memahami (Afangideh \& Jude, 2012). Menurut PISA (Beaton, 2005) dasar untuk mengukur kemampuan literasi membaca meliputi beberapa komponen berikut: Proses Tugas Membaca yaitu macammacam tugas yang dibutuhkan oleh pembaca yang meliputi (1) mendapatkan kembali informasi (2) mengembangkan interpretasi (3) merefleksikan isi dan struktur teks bacaan. Isi tipe-tipe teks bacaan yaitu bentuk materi tulisan yang dibagi menjadi dua tipe teks yaitu teks yang berkelanjutan (narasi, ekspositori, diskripsi, argumentasi dll) dan teks yang tidak berkelanjutan (diagram, peta, tabel, grafik dll). Maksud tujuan bacaan yaitu menggambarkan situasi bacaan yang sedang dibaca, dalam hal ini dapat berupa bacaan yang pribadi, bacaan dalam hal yang bersifat umum, bacaan yang berkaitan dengan pekerjaan atau bacaan yang berkaitan dengan pendidikan.

Pencapaian kemampuan literasi dalam membaca berhubungan dengan pengukuran kognitif, dan lebih penting lagi bahwa kemampuan kognitif dapat digunakan untuk memprediksi anak-anak dalam perkembangan literasi membacanya (Singleton, 2002). Frith (1992) mengemukakan bahwa untuk melihat kesulitan belajar seperti pada anak disleksia penting untuk melihat kaitan diantara perbedaan tingkatan dengan penjelasan yang berkaitan antara sebab-sebab biologis, kerusakan kognitif, dan perilaku seperti kekurangan dalam membaca dan mengeja.

Analisis kognitif tentang membaca berguna dalam memahami gejala terkait disleksia yang diakibatkan oleh kesurakan otak (Crisp dan Ralp, dalam Omrod, 2002). Lebih lanjut dijelaskan ada dua model disleksia terkait kerusakan otak, yaitu disleksia permukaan dan disleksia dalam bahwa pada kasus disleksia permukaan seseorang kehilangan kemampuan untuk melafalkan kata-kata berdasarkan ingatan spesifik tentang kata-kata, artinya mereka kehilangan prosedur leksikal, tetapi masih dapat menerapkan aturan-aturan pelafalan dalam 
membaca. Kesalahan yang sering dibuat adalah pelafalan pada kata-kata yang seolah-olah berirama sama. Adapun pada kasus disleksia dalam seseorang kehilangan kemampuannya untuk menerapkan aturan pelafalan dalam membaca, artinya seseorang kehilangan prosedur fonetik, tetapi masih dapat melafalkan kata-kata kongkret yang sudah dikenalnya berdasarkan ingatan spesifik tentang kata-kata.

\section{Kesadaran Phonologi}

Kesulitan membaca merupakan salah satu dari banyak pandangan yang merupakan gabungan disfungsi pada berbagai kondisi ketidaksempurnaan keadaan dari neurokognitif seseorang (Habib, 2011). Pada kenyataanya gangguan pada anak disleksia dapat dideteksi dari gangguan kesadaran penguasaan kosa kata dan metaphonologis (Vellutino, Fletcher, Snowling, Scanlon, 2004),

Hasil dari suatu penelitian mengungkapkan bahwa pengukuran kesadaran phonologi dapat mengungkap kemampuan membaca pada anak-anak (Bridges \& Catts, 2011). Kesadaran phonologi merupakan hal yang digunakan untuk mendiskripsikan secara khusus dan jelas kemampuan untuk memanipulasi kemampuan bicara pada tingkatan huruf (Kibby, 2009; Lundberg, Frost, \& Petersen, 1988), dengan kata lain bahwa seseorang dapat mengabstraksikan bunyi dengan intensitas yang berbeda dan merekognisi dalam kata dan menghasilkan kata baru. Lundberg (1988) mengajukan kategorisasi kesadaran phonologi menjadi tida tingkatan: 1) kemampuan suprasegmental, kemampuan untuk melakukan tugas memutuskan apakah kata tersebut mempunyai inisial yang sama atau memutuskan sebagai kata, 2) kemampuan syllabic merupakan tugas memisahkan kata dalam silabus dan memberikan atau menghilangkan silabus dari kata. 3) kemampuan phonemik mempunyai tugas untuk memisahkan dan mengumpulkan kembali kata-kata dalam rangkaian fonem.

Dalam teori phonologi dari disleksia, kemampuan untuk menghadirkan dan memanipulasi bunyi bahasa merupakan hal yang penting untuk menetapkan dan menjadikan secara otomatis hubungan suara dengan kata, yang mana secara tepat dan secara lancar merekognisi kata sampai proses pengkodean phonologi. Hal yang penting adalah hubungan antara kemampuan phonologi (dalam hal ini kesadaran phonologi) dan kemampuan membaca secara langsung. Dengan kata lain bahwa kekurang mampuan membaca dapat disebabkan karena kurangnya kesadaran phonologi ( Castles A, W ilson K, Coltheart M, 2011).

Keterkaitan kesadaran phonologi dengan literasi membaca

Ada kenyataan yang wajar bahwa kekurangan dalam kemampuan phonologi mempengaruhi kemampuan membaca. Ada hipotesis yang mereferensikan bahwa kekurangan phonologi pada anak yang kesadaran phonologi nya kurang secara umum menunjukkan kemampuan literasi membaca yang kurang pula, sehingga kurangnya dalam 
hal phonologi biasanya kurang juga dalam membaca (Snowling, 1981; Stanovich, 1988a; Stanovich \& Siegel, 1994).

Perbedaan individu dalam membaca dapat dilihat dari kesadaran phonologi dalam kemampuan membaca, meliputi segala bentuk kemampuan membaca, tidak hanya terdapat pada mereka yang kurang dapat membaca. Untuk itu, ada korelasi yang tinggi antara kesadaran phonologi dengan kecepatan membaca. (Ehri, 1989).

De Jong and Van der Leij (1999), menemukan bahwa perbedaan kesadaran phonologi pada siswa kelas 1 mempunyai dampak terhadap kemampuan membaca seperti juga pada saat awal membaca hitungan, yang mana aspek kesadaran phonologi untuk memprediksi kemampuan membaca.

Hipotesis

Ada hubungan antara kesadaran phonologi dengan literasi membaca

\section{METODE PENELITIAN}

Dalam tulisan ini penulis melakukan meta analisis terhadap hubungan antara kesadaran phonologi dengan literasi membaca. Dua puluh artikel, baik yang telah dipublikasikan melalui jurnal ilmiah maupun hasil penelitian disertasi yang dipublikasikan melalui internet 2001 hingga 2015 dianalisis dalam penelitian ini. Tujuannya adalah untuk melihat apakah variabel kesadaran phonologi yang diteliti dalam berbagai studi jika dirangkum ke dalam kerangka pikir variabel literasi membaca memberikan hasil yang konsisten atau bias dijadikan dasar untuk menjawab pertanyaan mengenai hubungan kesadaran phonologi dengan literasi membaca.

Data meta analisis ini diperoleh melalui penelusuran terhadap sejumlah studi utama yang dilakukan untuk menguji hubungan kesdaran phonologi dengan literasi membaca

Tabel 1. Data Penelitian

\begin{tabular}{|c|c|c|c|c|c|}
\hline NO & Peneliti & Judul & Tahun & variabel & Subyek \\
\hline 1 & $\begin{array}{l}\text { Thomson, J.M., } \\
\text { Leong, V., Goswami, } \\
\text { U }\end{array}$ & $\begin{array}{l}\text { Auditory processing interventions and } \\
\text { developmental dyslexia: a } \\
\text { comparison of phonemic and rhythmic } \\
\text { approaches }\end{array}$ & 2012 & $\begin{array}{l}\text { Phonological } \\
\text { Awerness - word } \\
\text { reading }\end{array}$ & Anak \\
\hline \multirow[t]{2}{*}{2} & \multirow[t]{2}{*}{$\begin{array}{l}\text { Howland, K.A, and } \\
\text { Liederman, J.L }\end{array}$} & \multirow{2}{*}{$\begin{array}{l}\text { Beyond Decoding: Adults With } \\
\text { Dyslexia Have Trouble Forming } \\
\text { Unified Lexical Representation s } \\
\text { Across Pseudoword Learnin g } \\
\text { Episodes }\end{array}$} & \multirow[t]{2}{*}{2013} & $\begin{array}{l}\text { 1. Phonological } \\
\text { Awerness - } \\
\text { Spoken }\end{array}$ & pelajar \\
\hline & & & & $\begin{array}{l}\text { 2. Phonological } \\
\text { Awerness - } \\
\text { Spoken }\end{array}$ & pelajar \\
\hline \multirow[t]{3}{*}{3} & \multirow[t]{3}{*}{$\begin{array}{l}\text { Christodoulou, J.A., } \\
\text { Del Tufo, S.N., } \\
\text { Lymberis,J., Saxler, } \\
\text { P.K., }\end{array}$} & \multirow[t]{3}{*}{$\begin{array}{l}\text { Brain Bases of Reading Fluency in } \\
\text { Typical Reading and Impaired } \\
\text { Fluency in Dyslexia }\end{array}$} & \multirow[t]{3}{*}{2014} & $\begin{array}{l}\text { 1. Phonological } \\
\text { Awerness - } \\
\text { reading fluency } \\
\text { (Slow) }\end{array}$ & \multirow[t]{3}{*}{ Anak } \\
\hline & & & & $\begin{array}{l}\text { 2. Phonological } \\
\text { Awerness - } \\
\text { reading fluency } \\
\text { (Medium) }\end{array}$ & \\
\hline & & & & $\begin{array}{l}\text { 3. Phonological } \\
\text { Awerness - }\end{array}$ & \\
\hline
\end{tabular}




\begin{tabular}{|c|c|c|c|c|c|}
\hline & & & & $\begin{array}{l}\text { reading fluency } \\
\text { (Fast) }\end{array}$ & \\
\hline 4 & Farris, E & $\begin{array}{l}\text { Characterizing and predicting growth } \\
\text { in reading skills in children with } \\
\text { developmental dyslexia through } \\
\text { functional neuroimaging }\end{array}$ & 2012 & $\begin{array}{l}\text { Phonological } \\
\text { Awerness - Reading } \\
\text { skill }\end{array}$ & Anak \\
\hline 5 & $\begin{array}{l}\text { Wang, X., Georgiou, } \\
\text { G.K., Das, J.P, and } \\
\text { Li, Q. }\end{array}$ & $\begin{array}{l}\text { Cognitive Processing Skills and } \\
\text { Developmental Dyslexia in Chinese }\end{array}$ & 2012 & $\begin{array}{l}\text { 1. Rymhme } \\
\text { Awerness - Reading } \\
\text { 2. Onset Awerness } \\
\text { - Reading }\end{array}$ & Anak \\
\hline 6 & $\begin{array}{l}\text { Anna S. Gellert, } \\
\text { Carsten Elbro }\end{array}$ & $\begin{array}{l}\text { Does a Dynamic Test of Phonological } \\
\text { Awareness Predict Early Reading } \\
\text { Difficulties? A Longitudinal Study } \\
\text { From Kindergarten Through Grade } 1\end{array}$ & 2015 & $\begin{array}{l}\text { 1. Static } \\
\text { Phonological } \\
\text { Awerness - Reading } \\
\text { skill } \\
\text { 2. Dinamyc } \\
\text { Phonological } \\
\text { Awerness - Reading } \\
\text { skill }\end{array}$ & Anak \\
\hline 7 & $\begin{array}{l}\text { Pacheco, A., Reis, A., } \\
\text { Arau'jo, S., Ina'cio, } \\
\text { F., Petersson, K.M., } \\
\text { and Faı'sca, L. }\end{array}$ & $\begin{array}{l}\text { Dyslexia heterogeneity: cognitive } \\
\text { profiling of Portuguese children with } \\
\text { dyslexia }\end{array}$ & 2014 & $\begin{array}{l}\text { Dinamyc } \\
\text { Phonological } \\
\text { Awerness - Reading } \\
\text { skill }\end{array}$ & Anak \\
\hline 8 & $\begin{array}{l}\text { Ferreira, J., } \\
\text { Rönnberg, J., } \\
\text { Gustafson, S, and } \\
\text { Wengelin, A. }\end{array}$ & $\begin{array}{l}\text { Literacy Skills in Children With Motor } \\
\text { and Speech Impairments }\end{array}$ & 2007 & $\begin{array}{l}\text { Dinamyc } \\
\text { Phonological } \\
\text { Awerness - Reading } \\
\text { skill }\end{array}$ & Anak \\
\hline 9 & $\begin{array}{l}\text { Jednoro'g, K., } \\
\text { Gawron, N., } \\
\text { Marchewka, A., Heim, } \\
\text { S, and Grabowska, A. }\end{array}$ & $\begin{array}{l}\text { Cognitive subtypes of dyslexia are } \\
\text { characterized by distinct patterns of } \\
\text { grey matter volume }\end{array}$ & 2014 & $\begin{array}{l}\text { Phonological } \\
\text { Awerness - Reading } \\
\text { skill }\end{array}$ & Anak \\
\hline 10 & Elbro, C & $\begin{array}{l}\text { Dyslexia as Disability or Handicap: } \\
\text { When Does Vocabulary Matter? }\end{array}$ & 2010 & $\begin{array}{l}\text { Phonological } \\
\text { Awerness - Spelling }\end{array}$ & Anak \\
\hline 11 & $\begin{array}{l}\text { McNeill, B.C, } \\
\text { Gillon,G.T, and } \\
\text { Dodd, B }\end{array}$ & $\begin{array}{l}\text { Effectiveness of an integrated } \\
\text { phonological awareness approach for } \\
\text { children with childhood apraxia of } \\
\text { speech (CAS) }\end{array}$ & 2009 & $\begin{array}{l}\text { Phonological } \\
\text { Awerness - speech } \\
\text { apraxia }\end{array}$ & Anak \\
\hline \multirow[t]{2}{*}{12} & \multirow[t]{2}{*}{$\begin{array}{l}\text { Rachel Schiff and } \\
\text { Einav Lotem }\end{array}$} & \multirow{2}{*}{$\begin{array}{l}\text { Effects of phonological and } \\
\text { morphological awareness on } \\
\text { children's word reading development } \\
\text { from two socioeconomic backgrounds }\end{array}$} & 2010 & $\begin{array}{l}\text { 1. Phonological } \\
\text { Awerness - Reading } \\
\text { skill grade } 4\end{array}$ & \multirow[t]{2}{*}{ Anak } \\
\hline & & & & $\begin{array}{l}\text { 2. Phonological } \\
\text { Awerness - Reading } \\
\text { skill grade } 6\end{array}$ & \\
\hline 13 & $\begin{array}{l}\text { Hemmi, J. N., } \\
\text { Myllyluoma, B., } \\
\text { Voutilainen, A., and } \\
\text { Leinonen, S. (2002) }\end{array}$ & $\begin{array}{l}\text { Familial dyslexia: Neurocognitive and } \\
\text { genetic correlation in a large Finnish } \\
\text { family }\end{array}$ & 2002 & $\begin{array}{l}\text { Phonological } \\
\text { Awerness - speech } \\
\text { apraxia }\end{array}$ & Anak \\
\hline 14 & $\begin{array}{l}\text { Meyler, A and } \\
\text { Breznitz, Z }\end{array}$ & $\begin{array}{l}\text { Impaired Phonological and } \\
\text { Orthographic Word Representations } \\
\text { Among }\end{array}$ & 2005 & $\begin{array}{l}\text { Phonological } \\
\text { Awerness - } \\
\text { kecepatan reading }\end{array}$ & Anak \\
\hline 15 & $\begin{array}{l}\text { Stuart Rosen, S., and } \\
\text { Manganari , E }\end{array}$ & $\begin{array}{l}\text { Is there a Relationship Between } \\
\text { speech and nonspeech auditory } \\
\text { processing children with dyslexia }\end{array}$ & 2001 & $\begin{array}{l}\text { Phonological } \\
\text { Processing - } \\
\text { Reading skill } \\
\end{array}$ & Anak \\
\hline 16 & $\begin{array}{l}\text { Bandini, H.H.M., } \\
\text { Santos, F.H., and de } \\
\text { Souza, D.G. }\end{array}$ & $\begin{array}{l}\text { Levels of Phonological Awareness, } \\
\text { Working Memory, and Lexical } \\
\text { Knowledge in Elementary School } \\
\text { Children }\end{array}$ & 2001 & $\begin{array}{l}\text { Phonological } \\
\text { Awerness - Reading } \\
\text { skill }\end{array}$ & Anak \\
\hline 17 & $\begin{array}{l}\text { Townsend, M, and } \\
\text { Konold, T.R }\end{array}$ & $\begin{array}{l}\text { Measuring Early Literacy Skills: A } \\
\text { Latent Variable Investigation of the } \\
\text { Phonological Awareness Literacy } \\
\text { Screening for Preschool }\end{array}$ & 2010 & $\begin{array}{l}\text { Phonological } \\
\text { Awerness - Reading } \\
\text { Comprehension }\end{array}$ & Anak \\
\hline 18 & $\begin{array}{l}\text { Casalis, S, and Colé, } \\
\text { P. }\end{array}$ & $\begin{array}{l}\text { On the relationship between } \\
\text { morphological and phonological } \\
\text { awareness: Effects of training in } \\
\text { kindergarten and in first-grade } \\
\text { reading }\end{array}$ & 2009 & $\begin{array}{l}\text { 1. Phonological } \\
\text { Awerness - Word } \\
\text { Reading } \\
\text { 2. Phonological } \\
\text { Awerness - Text } \\
\text { Reading }\end{array}$ & Anak \\
\hline
\end{tabular}




\begin{tabular}{l|l|l|l|l|l}
\hline 19 & $\begin{array}{l}\text { Gernand, K.L, and } \\
\text { Moran, M.J. }\end{array}$ & $\begin{array}{l}\text { Phonological Awareness Abilities of } \\
\text { 6-Year-Old Children With Mild to } \\
\text { Moderate Phonological Impairments }\end{array}$ & 2007 & $\begin{array}{l}\text { Phonological } \\
\text { Awerness - Reading } \\
\text { skill }\end{array}$ & Anak \\
\hline 20 & $\begin{array}{l}\text { Marshall, C.M., } \\
\text { Snowling, M.J.,and } \\
\text { Bailey, P.J. }\end{array}$ & $\begin{array}{l}\text { Rapid Auditory Processing and } \\
\text { Phonological Ability in Normal Reader } \\
\text { and Reader With Dyslexia }\end{array}$ & 2001 & $\begin{array}{l}\text { Phonological } \\
\text { Deletion- Word } \\
\text { Reading }\end{array}$ & Anak \\
\hline
\end{tabular}

\section{Sumber Data}

Data dalam penelitian ini bersumber pada studi literatur yang menguji keterkaitan kesadaran phonologi dengan literasi membaca. Studi literatur diperoleh melalui database online dan jurnal-jurnal di perpustakaan, terbitan tahun 2001 sampai dengan tahun 2015. Database online yang ditelusuri melalui Pro-Quest, Springer-link, EBSCO, Sagepub Online, maupun search engine Google Scholar. Adapun kata kunci yang digunakan dalam pencarian adalah phonological awarness, literacy, dyslexia, learning disability, reading impairment. Semua temuan artikel yang diperoleh kemudian dipertimbangkan dan diseleksi menurut kriteria sebagai syarat untuk dapat dilakukan kajian meta analisis.

Melalui penelusuran tersebut, diperoleh 20 naskah yang mengemukakan hubungan kesadaran phonologi dengan literasi membaca, dan ada beberapa artikel penelitian yang membagi kesadaran phonologi memjadi beberapa aspek untuk diteliti sehingga jumlah variabel yang diteliti menjadi 27 variabel kesadaran phonologi dengan literasi membaca (Tabel 1).

Analisis Data meta analisis korelasi

Analisis data dengan menggunakan tekhnik meta analisis, namun terlebih dahulu dilakukan koreksi terhadap artefak atau ketidaksempurnaan penelitian. Meta analisis digunakan sebagai dasar untuk menolak atau menerima hipotesis yang diajukan. Dalam penelitian ini akan dilakukan dua artefak yang dianalisis, yaitu kesalahan sampling dan kesalahan pengukuran (Hunter \& Smith, 1990):

Meta analisis korelasi bertujuan untuk mendapatkan distribusi sesungguhnya dari korelasi antara suatu variabel bebas dengan variabel tergantung (Hunter \& Schidt, 2004). Dalam kajian ini, variabel yang diukur adalah kesadaran phonologi sebagai variabel bebas $(x)$ dan literasi membaca sebagai variabel tergantung $(\mathrm{y})$.

Studi individual tidak pernah sempurna karena beberapa artefak yang menyertainya, yaitu kesalahan pengambilan sampel, kesalahan pengukuran, dikotomisasi, rentang variasi variabel, deviasi struktur variabel, kesalahan transkip, dan pengaruh eksternal lainnya. Kajian ini mencakup kesalahan pengambilan sampel yang merupakan kesalahan paling berpengaruh (Hunter \& Schmidt, 2004).

\section{HASIL DAN PEMBAHASAN}

Berikut studi yang digunakan sebagai sampel penelitian pada kajian meta analisis. Observasi data pada 27 studi di atas dilakukan pada rentang tahun 2001 sampai dengan 
2015. Lokasi observasi dari studi-studi tersebut mencakup penelitian di Asia, Eropa dan Amerika. Hasil seleksi terhadap data yang tersedia dapat dilihat pada tabel 1 berupa datadata yang memenuhi syarat untuk meta analisis.

Tahapan meta analisis (Hunter \& Schmidt, 2004) yang dilakukan dalam kajian ini adalah:

1. Mengidentifikasi nilai ri setiap studi baik secara langsung maupun dari nilai $F, t$, atau $d$. Terdapat 4 studi merupakan penelitian yang menghasilkan nilai $F, 3$ studi yang merupakan penelitian perbandingan yang menghasilkan nilai t, 2 studi yang menghasilkan nilai d, 18 studi yang merupakan penelitian korelasional yang menghasilkan nilai $r$. Nilai $F$ perlu ditransformasikan terlebih dahulu ke dalam nilai $t$, $d$ dan $r$. Adapun persamaan rumus aljabar disajikan sebagai berikut :

$$
\begin{aligned}
& \mathrm{T}=\sqrt{\mathrm{F}}=\mathrm{d}=2 \mathrm{t} \\
& \sqrt{ } \mathrm{N} \\
& \mathrm{d}=2 \mathrm{r} \\
& \sqrt{ }\left(1-r^{2}\right) \\
& \sqrt{ }\left(4+d^{2}\right)
\end{aligned}
$$

Terdapat dua puluh tujuh penelitian (tabel 2) mengenai hubungan kesadaran phonologi dengan kemampuan literasi membaca yang dipublikasikan dalam periode tahun 2001-2015 melibatkan total subjek penelitian 3.082 orang. Angka korelasi $r$ yang dilaporkan sangat bervariasi berkisar dari $0.19-$ 0.89. Nilai $r=0.19$ dilaporkan oleh Casilas \& Cole (2009), sedangkan nilai $r$ tertinggi sebasar $=0.89$ dilaporkan oleh Thomson, Leong dan Guswami (2005).

Menurut Hunter \& Schmidt (2004) bahwa informasi statistik yang harus ada dalam setiap studi meta analisis adalah ukuran sampel dan effect size. Effect size yang diperlukan adalah r. Namun demikian, jika tidak ada informasi $r$, effect size yang lain yaitu $d$, $t$ atau $F$ dapat pula digunakan untuk kemudian dikonversikan ke dalam bentuk $r$.

2. Melakukan koreksi kesalahan pengambilan sampel

Kesalahan pengambilan sampel (sampling error) adalah artefak yang paling banyak mencemari hasil penelitian. Menurut Hunter \& Schmidt (2004) bahwa kesalahan sampling ini memberikan dampak tidak terstruktur dan sangat dipengaruhi oleh besarnya ukuran sampel yang digunakan. Oleh karena itu, koreksi terhadap kesalahan dalam pengambilan sampel, penting untuk dilakukan terhadap data penelitian mengenai variabel yang sama sehingga diperoleh pola hubungan yang lebih konsisten menganai variabel yang diuji.

Koreksi kesalahan pengambilan sampel dilakukan dengan langkah-langkah berikut :

a) Menghitung mean ri (rerata korelasi populasi)

$$
\check{\mathrm{r}}=\frac{\sum(\mathrm{Ni} \mathrm{ri})}{\sum \mathrm{Ni}}
$$

Untuk menghitung koreksi kesalahan pengambilan sampel, ditunjukkan pada tabel 3. Rerata korelasi populasi setelah dikoreksi dengan jumlah sampel (̌r ) sebesar 0.53. Nilai ini 
menunjukkan bahwa kesadaran phonologi merupakan variabel yang mempengaruhi literasi membaca meskipun pengaruhnya tidak besar.

b) Menghitung varians ri

$$
\sigma^{2} \mathrm{r}=\frac{\sum\left(\mathrm{Ni}(\mathrm{ri}-\check{\mathrm{r}})^{2}\right.}{\sum \mathrm{Ni}}
$$

Hasil perhitungan varians rxy disajikan berikut ini dalam tabel 2.

\begin{tabular}{|c|c|c|c|c|c|c|c|}
\hline No & Peneliti & $\mathbf{N}$ & ri & $\mathbf{N} \times$ ri & ri-r xy & $(r i-r x y)^{2}$ & $N(r i-r x y)^{2}$ \\
\hline 1. & $\begin{array}{l}\text { Thomson, J.M., } \\
\text { Leong, V., } \\
\text { Goswami, U }\end{array}$ & 12 & 0.89 & 10,68 & 0,75 & 0,5625 & 6,75 \\
\hline 2. & \multirow{2}{*}{$\begin{array}{l}\text { Howland, K.A, and } \\
\text { Liederman, J.L }\end{array}$} & 20 & 0.21 & 4,20 & 0,07 & 0,0049 & 0,098 \\
\hline 3. & & 20 & 0.53 & 10,60 & 0,39 & 0,1521 & 3,042 \\
\hline 4. & \multirow{3}{*}{$\begin{array}{l}\text { Christodoulou, } \\
\text { J.A., Del Tufo, } \\
\text { S.N., Lymberis,J., } \\
\text { Saxler, P.K., }\end{array}$} & 12 & 0.69 & 8,28 & 0,55 & 0,3025 & 3,63 \\
\hline 5. & & 12 & 0.54 & 6,48 & 0,4 & 0,16 & 1,92 \\
\hline 6. & & 12 & 0,28 & 3,36 & 0,14 & 0,0196 & 0,2352 \\
\hline 7. & Farris, E & 30 & 0,58 & 17,40 & 0,44 & 0,1936 & 5,808 \\
\hline 8. & \multirow{2}{*}{$\begin{array}{l}\text { Wang, X., } \\
\text { Georgiou, G.K., } \\
\text { Das, J.P, and Li, } \\
\text { Q. }\end{array}$} & 160 & 0,46 & 73,60 & 0,32 & 0,1024 & 16,384 \\
\hline 9. & & 160 & 0,47 & 75,20 & 0,33 & 0,1089 & 17,424 \\
\hline 10. & $\begin{array}{l}\text { Anna S. Gellert, } \\
\text { Carsten Elbro }\end{array}$ & 36 & 0,37 & 13,32 & 0,23 & 0,0529 & 1,9044 \\
\hline 11. & $\begin{array}{l}\text { Pacheco, A., Reis, } \\
\text { A., Arau'jo, S., } \\
\text { Ina'cio, F., } \\
\text { Petersson, K.M., } \\
\text { and Faı'sca, L. }\end{array}$ & 12 & 0,48 & 5,76 & 0,34 & 0,1156 & 1,3872 \\
\hline 12. & $\begin{array}{l}\text { Ferreira, J., } \\
\text { Rönnberg, J., } \\
\text { Gustafson, S, and } \\
\text { Wengelin, A. }\end{array}$ & 46 & 0,61 & 28,06 & 0,47 & 0,2209 & 10,1614 \\
\hline 13. & $\begin{array}{l}\text { Jednoro'g, K., } \\
\text { Gawron, N., } \\
\text { Marchewka, A., } \\
\text { Heim, S, and } \\
\text { Grabowska, A. }\end{array}$ & 165 & 0,41 & 67,65 & 0,27 & 0,0729 & 12,0285 \\
\hline 14. & Elbro, C & 12 & 0,74 & 8,88 & 0,6 & 0,36 & 4,32 \\
\hline 15. & \multirow{2}{*}{$\begin{array}{l}\text { McNeill, B.C, } \\
\text { Gillon,G.T, and } \\
\text { Dodd, B }\end{array}$} & 199 & 0,42 & 83,58 & 0,28 & 0,0784 & 15,6016 \\
\hline 16. & & 199 & 0,50 & 99,50 & 0,36 & 0,1296 & 25,7904 \\
\hline 17. & $\begin{array}{l}\text { Rachel Schiff and } \\
\text { Einav Lotem }\end{array}$ & 24 & 0,73 & 17,52 & 0,59 & 0,3481 & 8,3544 \\
\hline 18. & $\begin{array}{l}\text { Hemmi, J. N., } \\
\text { Myllyluoma, B., } \\
\text { Voutilainen, A., } \\
\text { and Leinonen, S. } \\
(2002)\end{array}$ & 33 & 0,87 & 28,71 & 0,73 & 0,5329 & 17,5857 \\
\hline 19. & $\begin{array}{l}\text { Meyler, A and } \\
\text { Breznitz, Z }\end{array}$ & 17 & 0,22 & 3,74 & 0,08 & 0,0064 & 0,1088 \\
\hline 20. & $\begin{array}{l}\text { Stuart Rosen, S., } \\
\text { and Manganari, E }\end{array}$ & 254 & 0,58 & 147,32 & 0,44 & 0,1936 & 49,1744 \\
\hline 21. & $\begin{array}{l}\text { Bandini, H.H.M., } \\
\text { Santos, F.H., and } \\
\text { de Souza, D.G. }\end{array}$ & 458 & 0,44 & 642,40 & 0,3 & 0,09 & 131,4 \\
\hline
\end{tabular}

Tabel 2. Data penelitian koreksi kesalahan sampling 


\begin{tabular}{l|l|l|l|l|l|l|l}
\hline 22. & Townsend, M, and & 22 & 0,19 & 4,18 & 0,05 & 0,0025 & 0,055 \\
\cline { 3 - 7 } 23. & Konold, T.R & 22 & 0,41 & 9,02 & 0,27 & 0,0729 & 1,6038 \\
\hline 24. & $\begin{array}{l}\text { Casalis, S, and } \\
\text { Colé, P. }\end{array}$ & 25 & 0,62 & 15,50 & 0,48 & 0,2304 & 5,76 \\
\hline 25. & $\begin{array}{l}\text { Gernand, K.L, and } \\
\text { Moran, M.J. }\end{array}$ & 82 & 0,73 & 59,86 & 0,59 & 0,3481 & 28,5442 \\
\hline 26. & $\begin{array}{l}\text { Marshall, C.M., } \\
\text { Snowling, M.J., and } \\
\text { Bailey, P.J. }\end{array}$ & 18 & 0,65 & 11,70 & 0,51 & 0,2601 & 4,6818 \\
\cline { 3 - 7 } 27. & 18 & 0,73 & 13,14 & 0,59 & 0,3481 & 6,2658 \\
\hline & Jumlah & 2.080 & & & & & 380,0186 \\
\hline & Rerata & 114,48 & 0,5314 & & & & 14,074763 \\
\hline
\end{tabular}

Tabel 3 berikut menjelaskan lebih lanjut mengenai proses penghitungan untuk varians.

Berdasarkan tabel 3, diketahui bahwa varians rxy atau $\sigma^{2}$ r sebesar 0,1393

c) Menghitung varians kesalahan pengambilan sampel

Selanjutnya varians kesalahan pengambilan sampel dihitung dengan lebih dahulu menghitung rata-rata ukuran sampel sesuai persamaan berikut :

$$
\sigma^{2} \mathrm{e}=\underline{\left(1-\check{\mathrm{r}}^{2}\right)^{2}}
$$

$(\mathrm{N}-1)$

Bedasarkan nilai ř yang diperoleh dan rerata jumlah sampel $\mathrm{N}$, yang ada maka varians kesalahan pengambilan sampel pada studi meta analisis ini :

$$
\begin{aligned}
& \sigma^{2} \mathrm{e}= \frac{\left(1-0.0196^{2}\right)^{2}}{(77,03-1)} \\
&= \underline{0,980}=0,0126 \\
& 76,03
\end{aligned}
$$

Varians kesalahan pengambilan sampel $\sigma^{2}$ e sebesar 0.0126

d) Estimasi varians korelasi terkoreksi kesalahan pengambilan sampel

$$
\begin{aligned}
& \sigma^{2} p=\sigma^{2} r-\sigma^{2} \mathrm{e} \\
& \sigma^{2} p=0,1393-0.0126 \\
& \boldsymbol{\sigma}^{2} \mathbf{p}=0,1267
\end{aligned}
$$

Dengan standar deviasinya adalah $\sigma p=\sqrt{ } 0,1267=0.3559$

e) Interval Kepercayaan

Jika korelasi populasi setelah dikoreksi dengan jumlah sampel (ř ) memiliki distribusi normal, maka interval kepercayaan dihitung dengan persamaan berikut ini :

$$
\begin{aligned}
& \check{\mathrm{r}} \pm 1.96 \mathrm{SD} \\
& \check{\mathrm{r}} \pm 1.96 \sqrt{ } \sigma^{2} \mathrm{p} \\
& \check{\mathrm{r}} \pm 1.96 \sqrt{ } 0,1267 \\
& \check{\mathrm{r}} \pm 1.96 \times 0.356 \\
& 0.14 \pm 0.697=\mathbf{- 0 , 5 9 1}<\check{\mathbf{r}}<\mathbf{0 , 8 3 7}
\end{aligned}
$$


maka dapat disimpulkan bahwa korelasi populasi pada semua studi adalah positif. Berdasarkan hasil di atas, maka nilai ř dapat diterima dengan demikian dapat dikatakan bahwa penelitian ini mempunyai interval kepercayaan yang baik.

Dampak kesalahan pengambilan sampel dihitung sebagai berikut :

f) Menghitung dampak kesalahan pengambilan sampel

$$
\begin{aligned}
& \mathrm{R}=\underline{\sigma^{2} \mathrm{p}} \\
& \mathrm{\sigma ^{2 } \mathrm { r }}=\underline{0,1267}=0.9095 \\
& 0.1393
\end{aligned}
$$

Dari perhitungan ini diperoleh kesimpulan bahwa reliablitias (keandalan) nilai korelasi adalah sebesar $90.95 \%$ atau varians kesalahan pengambilan sampel sebesar $9.09 \%$. Nilai ini menunjukkan bahwa hasil pengukuran dengan pendekatan meta analisis ini memiliki tingkat keandalan yang cukup besar dengan kesalahan pengambilan sampel yang relatif kecil.

Adapun berkaitan dengan penghitungan kesalahan pengukuran tidak dihitung karena sedikitnya jumlah data penelitian yang mencantumkan reliabilitas alat ukur. Dari 20 data penelitian hanya 4 artikel yang mencantumkan data penelitian dengan koefisien reliabilitas sebesar 0,93, 0,93, 0,83 dan 0,63,sehingga kurang memenuhi syarat untuk dilakukan kesalahan pengukuran.

Meta analisis dilakukan dengan tujuan untuk memperoleh nilai korelasi populasi yang sebenarnya dengan mengoreksi kesalahan pengambilan sampel, sehingga diperoleh kesimpulan berkenaan hasil korelasi antara variabel. Dari hasil meta analisis yang dilakukan berdasarkan kesalahan pada pengambilan sampel diperoleh kesimpulan bahwa korelasi populasi (ř) setelah dikoreksi oleh kesalahan sampel diestimasikan sebesar 0.53 , varians populasi $\left(\sigma^{2}\right.$ p) sebesar dan standar deviasi sebesar 0.1267. Interval kepercayaan 90\% dengan batas penerimaan antara $-0.591<\check{r}<0.8791$. Hasil ini menunjukkan bahwa hipotesis yang menyatakan bahwa ada hubungan antara kesadaran phonologi dengan literasi membaca dapat diterima.

Hasil analisis data pada studi meta analisis tentang hubungan antara kesadaran phonologi dengan literasi membaca menunjukkan bahwa hubungan tersebut tergolong sedang dengan korelasi sebesar 0.53. Hasil ini dapat memiliki bahwa memang terbukti bahwa ada hubungan antara kesadaran phonologi dengan literasi membaca. Namun besaran koefisien korelasinya tidaklah tergolong besar. Goswami, (1999), Lundberg \& Snowling, (2000), melaporkan ada hubungan antara kemampuan phonologi dengan kemampuan membaca pada anak disleksia. Literatur mengenai hubungan anrata kemampuan pohologi dengan literasi membaca merupakan hal yang subtansial. Kekurangan dalam kemampuan phonologi mempengaruhi kemampuan membaca. Ada hipotesis yang mereferensikan bahwa 
kekurangan phonologi pada anak yang kesadaran phonologi nya kurang secara umum menunjukkan kemampuan literasi membaca yang kurang pula, sehingga kurangnya dalam hal phonologi biasanya kurang juga dalam membaca (Snowling, 1981; Stanovich, 1988a; Stanovich \& Siegel, 1994).

\section{KESIMPULAN}

Kemampuan literasi sangat penting bagi individu khususnya bagi siswa yang masih bersekolah. Ketidakmampuan belajar khususnya kesulitan dalam merekognisi kata, pengucapan dan pengkodean phonologi pada anak atau individu dengan kesulitan literasi bahasa membutuhkan perhatian khusus, sehingga penanganan terhadap mereka menjadi tepat.

Banyak faktor yang berkorelasi mempengaruhi kemampuan litarasi membaca pada individu dengan kesuitan belajar, baik secara kognitif maupun neuropsikologi. Salah satu yang mempengaruhi literasi membaca dari temuan diatas adalah kesadaran phonologi. Kesadaran phonologi merupakan bentuk kemampuan individu baik secara visual maupun auditori berkaitan dengan pemahaman terhadap huruf. Sebagaimana individu dengan disleksia mengalami gangguan literasi membaca berkaitan dengan kemampuan membedakan huruf serta mengucapkan kata. Kesadaran phonologi berkaitan dengan ketidakmampuan dan membaca, kemampuan yang kurang dalam phonologi juga secara langsung dapat mempengaruhi ketidakmampuan dalam membaca. Pembaca dengan kekurangan dalam kesadaran phonologi cenderung mempunyai kemampuan literasi membaca yang kurang pula.

\section{DAFTAR PUSTAKA}

Afangideh, M.E \& Jude, W.I. (2012). Developing Literacy SkillTo Enhance Academic Performance Of Learners In UYO Education Zone. Academic Research International. Journal Social Sceince Humanities. Vol.3. No.3.

Bandini, H.H.M., Santos, F.H., \& de Souza, D.G. (2001). Levels of Phonological Awareness, Working Memory, and Lexical Knowledge in Elementary School Children. Paidéia. Vol. 23, No. 56, 329-337. Paulo Research Foundation.

Beaton, A.A. (2004). Dyslexia, Reading and The Brain. Psychology Press 270 Medison Evenue: New York

Bridges, M. S., \& Catts, H. W. (2011). The use of a dynamic screening of phonological awareness to predict risk for read-ing disabilities in kindergarten children. Journal of Learning Disabilities, 44(4), 330-338. doi: 10.1177/0022219411407863

Casalis, S, \& Colé, P. (2009). On the relationship between morphological and phonological awareness: Effects of training in kindergarten and in first-grade reading. Firs Article. Vol 29(1): 113-142. sagepub.com 
Castles, A., Wilson, K., \& Coltheart, M. (2011). Early orthographic infl uences on phonemic awareness tasks: evidence from a preschool training study. J Exp Child Psychol 2011; 108: 203-10.

Christodoulou, J.A., Del Tufo, S.N., Lymberis, J., Saxler, P.K., Ghosh, S.S., Triantafyllou, C., Gabrieli, S.W., \& Gabrieli, J.D.E. (2014). Brain Bases of Reading Fluency in Typical Reading and Impaired Fluency in Dyslexia. PLOS ONE. www.plosone.org. July Vol. 9. Issue 7. e100552.

Elbro, C. (2013). Dyslexia as Disability or Handicap: When Does Vocabulary Matter? Brain Structur Function 219:1697-1707. Springerlink.com.

Farris, E.A., (2012). Characterizing And Predicting Growth In Reading Skills In Children With Developmental Dyslexia Through Functional Neuroimaging. Desertation. UMI Desertation Publishing. ProQuest LLC. 789 East Eisenhower Parkway P.O. Box 1346 Ann Arbor, Ml 48106 - 1346

Ferreira, J., Rönnberg, J., Gustafson, S., \& Wengelin, A. (2007). Literacy Skills in Children With Motor and Speech Impairments. Communication Disorders Quarterly. Volume 28 Number 4 236-251. Hammill Institute on Disabilities. sagepub.com

Frith, U. (2002). Cognitive Development And Cognitive Deficit. The Psychologist: Bulletin of The British Psychological Society, 5(1). 13-19.

Fuchs, D., \& Fuchs, L. S. (2006). Introduction to response to intervention: What, why, and how valid is it? Reading Research Quarterly , 41, 93-99.

Gellert, A.S., \& Elbro, C. (2015). Does a Dynamic Test of Phonological Awareness Predict Early Reading Difficulties? A Longitudinal Study From Kindergarten Through Grade 1. Journal of Learning Disabilities $1-11$. Hammill Institute on Disabilities. sagepub.com

Gernand, K.L., \& Moran, M.J. (2007). Phonological Awareness Abilities of 6-Year-Old Children With Mild to Moderate Phonological Impairments. Communication Disorders Quarterly. Volume 28 Number 4 206-215. sagepub.com

Guthrie, J.T., Alao, S., \& Rinehart, J.M. (1996). Engagemant In Reading For Young Adolescents. Journal of Adolescents And Adult Literacy. 40,4.348-446.

Hemmi, J. N., Myllyluoma, B., Voutilainen, A., \& Leinonen, S. (2002) Familial dyslexia: Neurocognitive and genetic correlation in a large Finnish family. Developmental Medicine and Child Neurology. 44, 9; ProQuest Nursing \& Allied Health Source. pg. 580

Hunter, JE \& Schmidt, FL. 1990. Methods of Meta-Analysis; Correcting Error and Bias in Research Findings. Newbury Park : Sage Publications.

Jednoro'g, K., Gawron, N., Marchewka, A., Heim, S, \& Grabowska, A. (2014). Cognitive subtypes of dyslexia are characterized by distinct patterns of grey matter volume. Brain Structure Function 219:1697-1707. Springerlink.com. 
Karole A. Howland, K.A., \& Liederman, J., (2013). Beyond Decod ing: Adults With Dyslexia Have Trouble Forming Unified Lexical Representation s Across Pseudowor d Learnin g Episodes. Journal of Speech, Language, and Hearing Research. Vol. 56N 10091022. American Speech-Language-Hearing Association.

Lundberg, I., Frost, J., \& Petersen, O.-P. (1988). Effects of an extensive program for stimulating phonological awareness in preschool children. Reading Research Quarterly, 23(3), 262-284.

Marshall, C.M., Snowling, M.J., \& Bailey, P.J. (2001). Rapid Auditory Processing and Phonological Ability in Normal Reader and Reader With Dyslexia. Journal of Speech, Language and Hearing Reaserch. Vol. 44. 925-940. American speech, language and hearing association.

McNeill, B.C., Gillon, G.T., \& Dodd, B. (2009). Effectiveness of an integrated phonological awareness approach for children with childhood apraxia of speech (CAS). Child Language Teaching and Therapy 25,3; pp. 341-366. sagepub.com

Meyler, A., \& Breznitz, Z. (2005). Impaired Phonological and Orthographic Word Representations Among. The Journal of Genetic Psychology. 166, 2; ProQuest Biology Journals. pg. 215

Pacheco, A., Reis, A., Arau'jo, S., Ina'cio, F., Petersson, K.M., \& Faı'sca, L. (2015). Dyslexia heterogeneity: cognitive profiling of Portuguese children with dyslexia. Journal of Reading Writing 27:1529-1545. Springer Science+Business Media Dordrecht.

Petrauskas, R \& Rourke, B. (1979). Identification of Subgroup of Retarded Readers : A Neuropsychological Multivariate Approach. Journal of Clinical Neuropsychology. I. 1737. In Larusso, M.L., Facoetti, A., Bakker, D.J. (2011). Neuropsychological Treatment of Dyslexia : Does Type of Treatment Matter? Journal of Learning Disabilities. 44(2),136-149.

Rosen, S., Manganari, E. (2001). Is there a Relationship Between speech and nonspeech auditory processing children with dyslexia. Journal of Speech, Language and Hearing Reaserch. Vol. 44. 720-736. American speech, language and hearing association.

Santrock, J.W. (2011). Educational Psychology. Jilid 2. Pustaka Pelajar. Yogyakarta

Schiff, R., \& Lotem, E. (2010). Effects of phonological and morphological awareness on children's word reading development from two socioeconomic backgrounds. First Language. 31(2) 139-163. Sagepub.com

Shaywitz, S.E \& Shaywitz B.A. (2003). Neurobiological Indices of Dyslexia. In L. Swanson, K. R. Harris \& S. Graham (Eds). Handbook of Learning Disabilities. (pp 514 -531). New York. NY; Guilford Press. In Nelson, A \& Ellison, P.A.T. (2009). The Neuropsychology of Women. Springer Science + Bussines Media. LCC. 
Shiel, G. (2002). Literacy Standards And Factor Affecting Literacy : In G. Raid \& J. Wearmourth (Eds). Diyslexia And Literacy. (131). John Welly and Son. USA

Singleton, C. (2002). Dyslexia: Cognitive Factor And Implication for Litaracy. In G. Raid \& J. Wearmourth (Eds). Dislexia and Literacy. John Wellly and Son. USA

Stanovich, K.E. (1991). Discrepancy definitions of reading disability: Has intelligence led us astray? Reading Research Quarterly, 26, 7-29.

Thomson, J.M., Leong, V., \& Goswami., U. (2012). Auditory processing interventions and developmental dyslexia: a comparison of phonemic and rhythmic approaches. Reading Writing Journal. Vol.26: 139-161. Springer Science+Business Media B.V

Townsend, M \& Konold, T.R. (2010). Measuring Early Literacy Skills: A Latent Variable Investigation of the Phonological Awareness Literacy Screening for Preschool. Journal of Psychoeducational Assessment. 28(2) 115 -128. sagepub.com

Wang, X., Georgiou, G.K., Das, J.P., \& Li, Q. (2012). Cognitive Processing Skills and Developmental Dyslexia in Chinese. Journal of Learning Disabilities 45(6) 526 -537. Hammill Institute on Disabilities. sagepub.com

Wolf, M., \& Bowers, P.G. (1999). The Double Deficit Hypothesis for The Developmental Dyslexias. Journal of Educational Psychology. 91, 415-438. In Larusso, M.L., Facoetti, A., Bakker, D.J. (2011). Neuropsychological Treatment of Dyslexia : Does Type of Treatment Matter? Journal of Learning Disabilities. 44(2),136-149.

Vellutino, F.R., Fletcher, J.M., Snowling, M.J., \& Scanlon, D.M. (2004). Specific Reading Disabilities (Dyslexia): What We Have Learned In The Past Four Decades? Journal of Child Psychology and Psychiatry. 45, 2-40. In Larusso, M.L., Facoetti, A., Bakker, D.J. (2011). Neuropsychological Treatment of Dyslexia : Does Type of Treatment Matter? Journal of Learning Disabilities. 44(2),136-149.. 